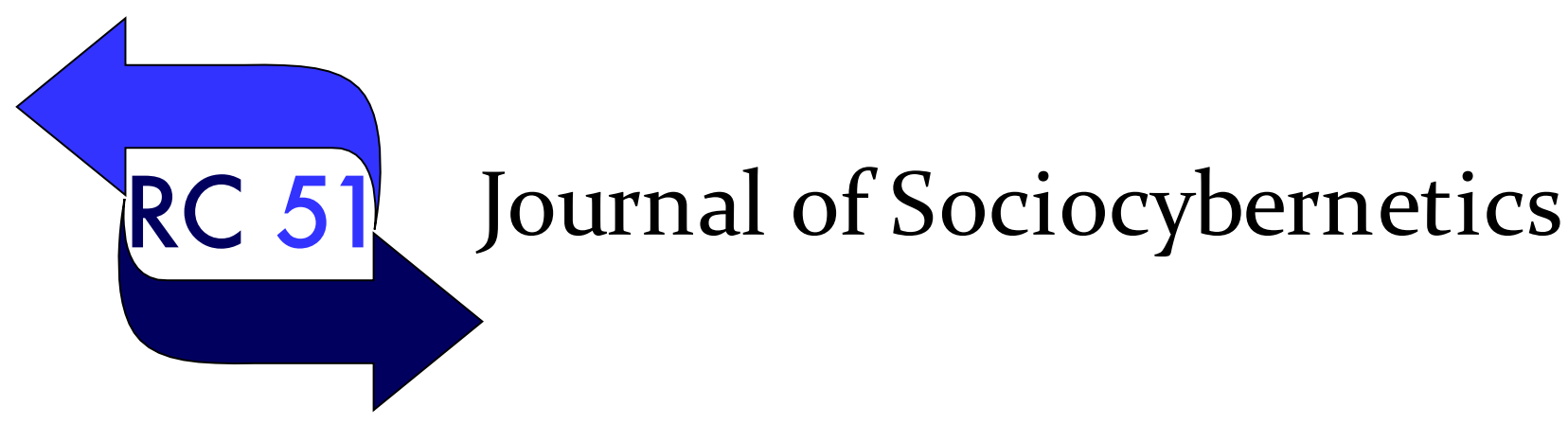

Journal of Sociocybernetics ISSN 1607-86667

\title{
Towards a complex system of personal and group characteristics for ICT appropriation
}

Daniel Montes Agudelo, Luz Arabany Ramirez Castañeda, Jheimer Julián Sepúlveda López

National University of Colombia, Manizales headquarters

\begin{abstract}
This research tackles the phenomenon of digital inclusion, considered as a type of social development that has grown, due to the advance of information and communication technologies (ICT). It is worth noting that, the "ICT advance" has not been uniformly distributed, since there is a difference regarding the access to technology, and to the use of it among groups and people. Though the governments, the organizations and the ICT institutions, recognize the social nature of the digital inclusion, and also, they are aware of the necessity of integrating communities and people, with the process of program and/or project management; these people and communities are not considered, in the proposals that are being made about this issue. Likewise, though it is clear in the revision of literature, the necessity of having quantitative and qualitative approaches, the numerical approach that is being performed in the phenomenon is evident. Additionally, it has been identified the fact that, there are diverse personal and social characteristics, that allow the appropriation of ICT tools, as well as their use to achieve goals and to improve the conditions, for participating in the employment, education and political activities. The digital inclusion is a situation that involves different factors, such as: cultural, technical, social, financial, regulatory, moral and even ecological. If this topic is tackled in a quantitative way, the aforementioned factors seem to be unrelated. However, in the literature analysis, their relation is obvious, as well as the fact that they cannot be unrelated form one another. In other words, the elements that conform the digital inclusion phenomenon, are not only heterogeneous, but also inter-definable. The former statement justifies the analysis of the digital inclusion phenomenon, as a complex system; since regarding the ICT appropriation, there is a wide variety of proposals, considering the personal and social variables, that regulate this process. Nevertheless, there is not yet a consensus about these variables, which is the proposal presented in this paper.
\end{abstract}

url:

\section{Introduction.}

The phenomenon of digital inclusion is understood, as a social phenomenon that has grown, due to information and communications technologies expansion (ICT). It is worth noting that, the "ICT growth" has not been uniform, since there is a difference in the access to technology and in the use of it, by groups and people. This difference in the ICT availability, the access to it and its use with civil purposes, is known as digital gap (Pick, Sarkar, \& Johnson, 2015). There have been diverse policies implemented by the governments, public and private institutions, with the expectation of minimizing this gap. These actions have made of internet, the technological product with the highest market penetration, over the last decades (Maldifassi and Canessa, 2009).

Corresponding author: Luz Arabany Ramirez Castañeda,, Julián Sepúlveda; e-mail: laramirezc@unal.edu.co 
For this research, we have used the definition of digital inclusion, appointed by Seale in 2010, and quoted by Thompson et al. (2014): "it is a phenomenon that marginalized people can use, to access and participate in a meaningful way, in the learning, employment, social and citizenship activities, in the same way that the rest of people do, by accessing to digital technologies, such as computers" (p.37).

Though the governments, organizations and institutions related to ICT, are aware of the social nature that the digital inclusion has, and also, that is necessary to involve people and communities in the management process (wording, implementation and assessment); these programs and/or projects, as well as people and communities related to them are not considered. Likewise, though it is clear in the revision of literature, the necessity of having quantitative and qualitative approaches, it is observed a repetitive numerical approach of the phenomenon (number of computers and tablets, number of internet connection points, number of workshops, number of scholars and demographic data).

The digital inclusion is a situation that involves diverse factors, such as: cultural, technical, social, financial, regulatory, moral and even ecological. If this topic is tackled in a quantitative way, the aforementioned factors seem to be unrelated. However, in the literature analysis, their relation is obvious, as well as the fact that they cannot be unrelated form one another. In other words, the elements that conform the digital inclusion phenomenon are not only heterogeneous, but also interdefinable.

The former statement justifies the analysis of the digital inclusion phenomenon, as a complex system; since regarding the ICT appropriation, there is a wide variety of proposals, considering the personal and social variables, that regulate this process. Some examples of this are: Sun and Zhang (2006) who present the moderating factors, Noce and McKeown (2008) who propose the Logistical Model; Billon, Marco and Lera-López (2009) who define the variable of digitalization, and Weber and Kauffman (2011) who establish the general factors. In addition to that, there are some proposals of models for these variables: Technology Acceptance Model -TAM (Eagleman, 2013), Dynamic and Heuristic Digital Inclusion Model - 2Id and the Digital inclusion 2iD and Heuristic - 2iDj Model (Teles \& Joia, 2010), Unified Theory of Acceptance and Use of Technology (UTAUT) (Gupta, Dasgupta, \& Gupta, 2008) and the Dynamic Multifaceted Model of the Digital Gap (DeHann, 2004).

There were not found any proposals about a consensus of these variables, which is the reason why, we have appointed a proposal for this purpose, consisting of: identifying variables by using diverse approaches, the unification of these variables, we have also considered elements that allow their classification, and we have created a complex system, in order to understand the relations that these variables have.

This research was the basis for developing the doctoral thesis "Social perspective of the digital inclusion phenomenon: an approach from complexity". In this thesis it was found, from a process of revision of state of the art, a necessity to identify the individual and social characteristics, for the adoption process of ICT, as well as the relations that are established among them. Additionally, it was also identified, that these personal and social characteristics could be a tool for ICT appropriation, in order to achieve goals and to improve the conditions of participation, for people in the civil activities (employment, education and policy).

The identification of personal and group characteristics, for the ICT appropriation and their relations, will allow to tackle the digital inclusion phenomenon, with a complex and multidimensional approach. The description of the digital inclusion phenomenon, through the simultaneous integration of social factors, allows focusing in one of the challenges of 
sociocybernetics, which is: "to generate an interdisciplinary approach, in order to have an interaction with the government, regarding social-complex obstacles" (Becerra, 2016, page 86). This idea is complemented, if we consider that the research in this paper is being carried out, in the Master of Information Systems Management of the National University of Colombia, which is an academic program that combines social (administrative) and technological factors (information systems).

This paper has been structured as follows: first, there is an approach to digital inclusion, where it is appointed the need of approaching the phenomenon as a complex system. Second, there is a revision of diverse proposals of personal and group characteristics, for the adoption and appropriation of ICT. Third, there is an initial approach for the consensus of individual and social characteristics, for the ICT appropriation. Fourth, it is appointed the next step, for establishing a complex-system model for these characteristics. And fifth, the conclusions for the research are displayed.

\section{Digital inclusion, a complex phenomenon?}

The background information about digital inclusion, shows that there is a general tendency - as a trend - of stating that is necessary to study this phenomenon, from the inter and transdisciplinarity. These factors are mostly related to complexity and to multidimensionality. However, in the definition of the problem, the selection of methodologies, and the statement of solutions for this situation, it was found that researchers generally carry out simple quantitative studies (especially with a demographic nature). The difficulty that was initially appointed is not over, just for being implemented and/or used.

When approaching to the digital inclusion phenomenon, there must be considered the external and internal contexts that conform it. The ICT cannot transform positively an individual or community by themselves, it is necessary that the participants of the projects, consider the requirements of the context, as well as, the peculiarities and specific necessities of the community, that is the "target" of the process. As stated by Pérez and Sarrate (2011) "The ICTs are not a goal per se, but a means, a tool that must be adapted for the diverse contexts".

Likewise, it is required an articulation among the actors that are related, to identify the needs and opportunities. The purpose is having a better performance of the processes that are started, with the objective of improving the social conditions, using ICT; and, that these processes have a higher reach and impact for the communities, besides offering access to technological tools.

The digital inclusion phenomenon requires a complex understanding, and an approach that allows several activities, as: considering its social perspective, integrating the community and its peculiar characteristics in the wording, implementing and assessing processes of the programs/projects that start, with the purpose of decreasing the digital gap.

Similar to the digital gap, the conceptualization of digital inclusion is still new, and it is under construction (Weerakkdy, et al. 2012). As a contribution for the conceptualization of digital inclusion, we present the following approach to a definition, worded by Sepúlveda, which started with a process of revision of literature and evolved, until being a concept appointed on his doctoral thesis:

The digital inclusion could be defined as a phenomenon that intends to offer availability of technological tools, contents and applications, for a group of people, with certain personal and social characteristics, that must be considered for a proper development of these processes. As a result, it is expected to have people increasing their participation, in activities related to citizenship, social, employment and learning, through the use of ICT products. 
This factor makes possible the community growth, which is interpreted as social inclusion of the community.

It could be stated that, this definition surpasses the quantitative and technological dimension, that the phenomenon of digital inclusion has only had, from its origins until now.

The phenomena of digital gap and digital inclusion involve several factors, such as: cultural, technical, social, financial, regulatory, moral and even ecological (Sepúlveda López \& Ramírez Castañeda, 2015). When the quantitative approach is performed, as it usually is, these factors seem to be independent, but during the literature analysis, it has been identified that they are related, and that is not possible to be taken apart. In other words, the elements that conform the digital inclusion phenomenon are heterogeneous and inter-definable.

Since the heterogeneity and inter-definability are characteristics of complex phenomena, it is used the definition that defines a complex system to be "a representation of a piece of this reality, conceptualized as an organized whole (hence the label of system), in which the elements are not "separable" and therefore, they could not be studied apart from one another" (Garcia, 2006).

Additionally, there must be considered the fact that, when studying a complex phenomenon, the researchers study a piece of the reality, that is composed by physical, biological, social, economic and political factors (Garcia, 2006).

The diverse definitions and perspectives in the digital gap and digital inclusion, reinforce the condition that describe them as complex situations that require serious thought at a micro, meso and macro level (Thompson, et al. 2014); it is important to check on the individual and social factors, as well as their relationship with the context.

It was identified that there are several statements, about the individual and social factors that conform these phenomena, however, each author proposes and uses only the factors that adjust to their research processes. There is no consensus among these factors, and neither a proposal of a system that connects them.

\section{Towards a complex system of personal and group characteristics for ICT appropriation}

In order to identify the proposals that state the individual and group characteristics, for the adoption and appropriation of ICT, it was carried out a process of systematic revision of literature, where it was formulated a search equation, that considered several relevant factors, in the phenomenon of gap and digital inclusion. This equation was used in different data bases (Scopus, Web of Science, Science Direct). From this process, there were found the proposals presented below, where the authors used different characteristics.

\subsection{Models for adoption and appropriation of ICT}

Sun and Zhang (2006) named as moderating factors, the characteristics for adoption and appropriation of ICT. These are factors that can explain the limited power, and the inconsistency among the diverse researches, about technology acceptance. Among these elements, we can find organizational, technological and individual factors. The authors emphasized that these factors, must be considered for the adoption of technology, in an organizational level.

The Logistics Model proposed by Noce and McKeown (2008) appointed that, some of the elements that influence the use of internet, seem to be varying in time. This model was proposed to identify the factors, that influence the use of internet in Canada, focusing on the importance of connectivity, for the rural remote communities, with the purpose of achieving equity on the internet access. 
Maldifassi and Canessa (2009) identified that, the utility of internet perceived by every person in Chile, is statistically linked with the people who belong to socio-economic groups, with the highest lifestyle and, where most of these people are young.

Billon, Marco and Lera-Lopez (2009) appointed that the digital gap, must also be understood from a great number of variables. They analyze the differences among countries regarding the use of ICT, and they also state that this is a multidimensional and complex phenomenon, that is based on political, institutional and cultural differences among the countries.

Schleife (2010) identified as individual characteristics: the level of education, the age and the salary, which could be great impediments for the internet access. Besides, the regional characteristics, such as the ICT infrastructure and the access cost, could determine the probability of individual access to technology.

Weber and Kauffman (2011) analyzed the general factors, to be considered for the ICT adoption. To these authors, the general digital gap, is the variation of technology access among the countries, through different ICT generations, i.e. the diverse variations in technological tools.

Almuwil, Weerakkody and El-Haddadeh (2011) identified that the digital gap has a complex nature, as well has multiple levels. It is a dynamic phenomenon that changes, every time that technology advances. They also state that, the current indicators are still focused on measuring wide factors, as the ICT access, internet connection, level of skills in digital literacy and usage rates of ICT.

Therefore, they conclude that, it is necessary to have a better construction and refinement, of the assessment variables for digital inclusion.

Michailidis, Partalidou, Nastis, Papadaki-Klavdianou and Charatsari (2011) analyzed the characteristics, to understand the use of internet, by people located in the rural area of Greece. To these authors, the use of this technology is prompted by several factors, such as: salary, genre, region and number of employees. Likewise, they define that, disseminating this technology is a complex process, where several components of social, economical, political and technological nature intervene.

Kubiatko (2013) made a comparison among the diverse age groups, in order to analyze the use of ICT, and he found that, people who belong to Y generation, perceive the ICT in a more positive way, compared to older people.

Taipale (2013) identified that the abilities and competences to use internet, vary according to genre, age and academic level. Whereas the place of residence, social status and family situation, are related to the needs of other services, that do not depend on ICT.

Pick, Sarkar and Johnson (2015) performed an analysis, where they appointed which are the factors to establish the use of ICT, in the developing countries. Among the most relevant factors, there are: the civil liberties, the political rights to access internet, the mobile telephone service and the use of computers.

Hinostroza, Matamala, Labbe, Claro and Cabello (2015) emphasized that, the use of ICT is conditioned mainly by cultural, social and economic backgrounds of the users; and also, by personal characteristics, such as academic level, genre and age. 
Papaioannou and Charalambous (2011) researched on the variables that determine the integration of ICT, in the elementary schools of Cyprus. The authors state that it is important to study this issue, since the elementary schools are educating the future citizens, in the use of technological products for daily and working life. In their research the authors found that, one of the variables to be considered, is the genre of the elementary school principal, because men and women, both have a positive attitude towards ICT, but are men who have a higher positive attitude.

Koç, Turan and Okursoy (2016) studied the adoption of mobile applications, in high schools in Turkey. They found that the new technologies provide new opportunities, and their adoption has become into a problem, for scholars and professionals. Therefore, these authors conclude that, it is an important matter to understand the factors that contribute to the intention of the users, towards the use of new mobile services.

Thill, Rosenzweig and Wallis (2016) designed a case study, to examine the relation between demographic characteristics and the commitment of the students, by using a module of directions, for an on-line library. In this case, the authors identified that, the characteristics of age and highergrade point average, were related to a high level of commitment, to follow the directions on line.

Finally, Nilashi, Ahmadi, Ahani, Ravangard and bin Ibrahim (2016) researched about the variables that determine the decision, of adopting information systems (IS) for hospitals in Malaysia. The authors identified that the most important dimensions considered, when making the decision of adopting IS, are the technology and context characteristics.

On Table 1, it is presented a summary of the authors and their corresponding proposal, for individual and/or group characteristics, for adoption and appropriation of ICT.

\begin{tabular}{|c|c|}
\hline Authors & Characteristics \\
\hline Sun and Zhang (2006) & $\begin{array}{l}\text { - Organizational factors: will and occupation/profession } \\
\text { - Technological factors: individual/groups, purpose and complexity } \\
\text { - Individual factors: intellectual capacity, culture, genre, age and } \\
\text { experience }\end{array}$ \\
\hline $\begin{array}{l}\text { Noce and McKeown } \\
(2008)\end{array}$ & $\begin{array}{l}\text { - Age } \\
\text { - Salary } \\
\text { - Geographic location } \\
\text { - Genre } \\
\text { - Academic level } \\
\text { - Language } \\
\text { - People under } 18 \text { years old at home }\end{array}$ \\
\hline $\begin{array}{l}\text { Maldifassi and Canessa } \\
(2009)\end{array}$ & $\begin{array}{l}\text { - Social class } \\
\text { - Academic level } \\
\text { - Age }\end{array}$ \\
\hline $\begin{array}{l}\text { Billon, Marco and Lera- } \\
\text { Lopez (2009) }\end{array}$ & $\begin{array}{l}\text { - Dependent variables: telephone line, personal computers, } \\
\text { international broadband internet, use of cell phone, internet } \\
\text { users, secure internet servers, broadband subscribers } \\
\text { - Independent variables: cost of Internet, GDP per capita, } \\
\text { percentage of population among } 15 \text { and } 64 \text { years old, population } \\
\text { density, rural population, government effectiveness and the level } \\
\text { of English use }\end{array}$ \\
\hline Schleife (2010) & $\begin{array}{l}\text { - Rural or Urbane } \\
\text { - Age } \\
\text { - Genre }\end{array}$ \\
\hline
\end{tabular}




\begin{tabular}{|c|c|}
\hline & $\begin{array}{l}\text { - Marital status } \\
\text { - Number of people at home } \\
\text { - Education } \\
\text { - Occupation } \\
\text { - Salary }\end{array}$ \\
\hline $\begin{array}{l}\text { Weber and Kauffman } \\
(2011)\end{array}$ & $\begin{array}{l}\text { - Economic factors } \\
\text { - Social factors of the ICT adoption } \\
\text { - Legal factors } \\
\text { - Context factors } \\
\text { - Environmental factors } \\
\text { - Cognitive factors }\end{array}$ \\
\hline $\begin{array}{l}\text { Almuwil, Weerakkody } \\
\text { and El-Haddadeh (2o11) }\end{array}$ & $\begin{array}{l}\text { - Demographic: age, marital status, race and ethnicity } \\
\text { - Economical: job, salary, urbanization } \\
\text { - Social: education, health, life style } \\
\text { - Cultural: language, knowledge, traditions }\end{array}$ \\
\hline $\begin{array}{l}\text { Michailidis, Partalidou, } \\
\text { nastis, Papadaki- } \\
\text { Klavdianou and } \\
\text { Charatsari (2011) }\end{array}$ & $\begin{array}{l}\text { - Salary } \\
\text { - Cost } \\
\text { - Genre } \\
\text { - Number of computers at home } \\
\text { - Number of young people at home } \\
\text { - Academic level } \\
\text { - Age } \\
\text { - Region } \\
\text { - Distance from the region to urban areas } \\
\text { - Number of employees } \\
\text { - Professional training }\end{array}$ \\
\hline Kubiatko (2013) & $\begin{array}{l}\text { - Age } \\
\text { - Genre } \\
\text { - Study path } \\
\text { - National origin }\end{array}$ \\
\hline Taipale (2013) & $\begin{array}{l}\text { - Sex } \\
\text { - Age } \\
\text { - Academic level }\end{array}$ \\
\hline $\begin{array}{l}\text { Pick, Sarkar and } \\
\text { Johnson (2015) }\end{array}$ & $\begin{array}{l}\text { - Demographic factors } \\
\text { - Urban location } \\
\text { - Economic factors } \\
\text { - Government support for education access } \\
\text { - Government investment on education and corporate investment } \\
\text { in IT, research, innovation and development }\end{array}$ \\
\hline $\begin{array}{l}\text { Hinostroza, Matamala, } \\
\text { Labbe, Claro and } \\
\text { Cabello (2015) }\end{array}$ & - Cultural, social and economic backgrounds of the users \\
\hline $\begin{array}{l}\text { Papaioannou and } \\
\text { Charalambous (2011) }\end{array}$ & $\begin{array}{l}\text { - Genre } \\
\text { - Years of service } \\
\text { - Academic qualifications } \\
\text { - Access to a computer at home } \\
\text { - Internet access at home } \\
\text { - Continuous training on ICT for teaching and learning purposes } \\
\text { - Existence of a computer in the director's office and experience } \\
\text { with the computer }\end{array}$ \\
\hline
\end{tabular}




\begin{tabular}{|c|c|}
\hline $\begin{array}{l}\text { Koç, Turan and Okursoy } \\
(2016)\end{array}$ & $\begin{array}{l}\text { - Context } \\
\text { - Trust } \\
\text { - Personal initiative } \\
\text { - Perceived usefulness } \\
\text { - Perceived facility of use } \\
\text { - Intention of use }\end{array}$ \\
\hline $\begin{array}{l}\text { Thill, Rosenzweig and } \\
\text { Wallis (2016) }\end{array}$ & $\begin{array}{l}\text { - Age } \\
\text { - Cumulative average } \\
\text { - Genre } \\
\text { - Race/ethnicity }\end{array}$ \\
\hline $\begin{array}{l}\text { Nilashi, Ahmadi, Ahani, } \\
\text { Ravangard and Bin } \\
\text { Ibrahim (2016) }\end{array}$ & $\begin{array}{l}\text { - Technological: relative advantage, compatibility, complexity and } \\
\text { security } \\
\text { - Organizational: presence of champions, infrastructure, } \\
\text { management support, hospital size and financial resources } \\
\text { - Context: mimetic pressure, coercive pressure, competence } \\
\text { intensity and support of suppliers } \\
\text { - Human: Perception of the technical competence of the IS } \\
\text { personnel, knowledge of the employees on IS, clinical experts on } \\
\text { IT and on Chief Information Officer (CIO) innovation }\end{array}$ \\
\hline
\end{tabular}

Table 1. Summary of characteristics. Source: Designed by the authors of this paper

The characteristics that were used in the diverse proposals, depend among other factors, on the type of situation that was analyzed. To some authors, the group characteristics are more relevant, e.g. the differences between countries or geographic areas. Other authors propose personal characteristics, such as age, genre or salary, as the characteristics that should be really considered, in order to explain the adoption and appropriation of ICT.

However, and as shown on table 1, the authors agree on establishing multiple variables, according to the dynamic and complex nature of the digital inclusion phenomenon. Hence, it is necessary to carry out a consensus of variables, that could be used in further researches, about adoption and appropriation processes of ICT.

\subsection{Initial approach to classification and consensus of the characteristics, for adoption and appropriation of ICT}

Based on the aforementioned matters, and in order to accomplish with the purpose of the research, we can fin below an initial proposal for classification of characteristics, based on: the statements noted by the authors, on the literature that was analyzed and, using the most frequently mentioned characteristics in the references.

There were gotten 157 variables, from the first revision of the 17 models that were found. As shown in table 2, 86 variables were defined by the authors, whereas 71 of them were not defined.

\begin{tabular}{|l|c|c|c|}
\hline \multicolumn{1}{|c|}{ Article } & $\begin{array}{c}\text { Number } \\
\text { of } \\
\text { variables }\end{array}$ & $\begin{array}{c}\text { Defined } \\
\text { Variables }\end{array}$ & $\begin{array}{c}\text { Variables not } \\
\text { defined }\end{array}$ \\
\hline Maldifassi y Canessa (2009) & 3 & & $\mathrm{x}$ \\
\hline Noce \& McKeown (2008) & 7 & & $\mathrm{X}$ \\
\hline Pick, Sarkar y Johnson (2015) & 7 & $\mathrm{X}$ & \\
\hline Schleife (2010) & 9 & $\mathrm{X}$ & \\
\hline Sun y Zhang (2006) & 10 & $\mathrm{X}$ & \\
\hline Weber y Kauffman (2011) & 6 & $\mathrm{X}$ & \\
\hline
\end{tabular}




\begin{tabular}{|l|c|c|c|}
\hline (Dang et al., 2011) & o & & \\
\hline $\begin{array}{l}\text { (Patricia Gonzalez-Zabala, Sanchez Torres, \& Galvis Lista, } \\
\text { 2015). }\end{array}$ & 30 & & $\mathrm{x}$ \\
\hline Kubiatko (2013) & 4 & & $\mathrm{x}$ \\
\hline Almuwil, Weerakkody y El-Haddadeh (2011) & 12 & $\mathrm{X}$ & \\
\hline Billon, Marco y Lera-Lopez (2009) & 19 & $\mathrm{X}$ & \\
\hline $\begin{array}{l}\text { Enrique Hinostroza, Matamala, Labbe, Claro y Cabello } \\
\text { (2015) }\end{array}$ & 6 & & $\mathrm{x}$ \\
\hline Taipale (2013) & 8 & & $\mathrm{x}$ \\
\hline (Papaioannou \& Charalambous, 2011) & 8 & & $\mathrm{x}$ \\
\hline (Koç et al., 2016) & 6 & $\mathrm{x}$ & \\
\hline (Thill et al., 2016) & 5 & & $\mathrm{x}$ \\
\hline (Nilashi et al., 2016). & 17 & $\mathrm{x}$ & $\mathbf{7 1}$ \\
\hline
\end{tabular}

Table 2. Identification of variables. Source: Designed by the authors of this paper.

Among the individual variables that were identified, we can note: Genre, Age, Academic level, Salary, Language, Social class, Marital status, ICT cost, Number of people at home, Race, Ethnicity, Number of computers at home, Location (urban, rural). And among the group variables, we can note: State policies, Laws, Government support, Culture and investment on IT by the state.

\section{Next step towards a complex system of characteristics, for adoption and appropriation of ICT}

To achieve a consensus of the personal and group characteristics, for the adoption and appropriation of ICT, that allows understanding this phenomenon from a complex and dynamic approach, it is proposed the use of Interpretation Structural Modeling (ISM), which is a methodology used to identify, the relations among the specific elements that determine a problem or issue (Attri, Dev, \& Sharma, 2013).

The ISM methodology has been used as a technique, to find relations among variables, that define a complex phenomenon in several fields: Dubey and Singh (2015) used it to find the relations among the variables, in the production industry, more precisely, in the manufacturing with a lean focus. Trivedi and Dubey (2012) implemented this methodology, to find the relations among the elements that compose the small and medium-sized enterprises in India, to perform the knowledge management. Tuan (2017) used this methodology, to understand the relation among the diverse factors, that cause South Africa to have a high rate of HIV infections.

The ISM methodology consists of three steps: (i) identifying the variables and relations, (ii) making a structural similarity index matrix (SSIM), which is developed based on the comparison of variable pairs, (iii) making the matrix SSIM in a reachability matrix (RM) and finding its transitivity. Once the transitivity is confirmed, it is obtained a matrix model (Entezari, 2015). For the specific case of the research in this paper, in addition to the development of the steps for the ISM methodology, there will be performed a validation of the model, by experts on digital inclusion, which purpose is to adjust the consensus of the model that is proposed.

This methodology was chosen, since it allows finding a context relation, within a group of variables that conform a matter or issue. In this case, the matter is the adoption/appropriation of ICT and the factors that influence it, as well as the individual and group variables that were identified along the revision of literature. Another reason to use this methodology is, as noted by Watson (1978), that the most relevant problems of this age seem to be more frequent, between the interface of technology and society. Thus, these issues go beyond the limit of diverse social, economic, political, 
institutional, environmental and technological systems. The aforementioned factors, make of this issue a complex matter, allowing the appointed methodology to find this type of relations, in a complex and multidimensional context. Finally, as the phenomena of digital gap and digital inclusion are framed in a social context, it is necessary to have a interpretation method, which allows understanding the context of the variables and developing the relations among them. As appointed by Tuan (2017), when he notes that the systematic thought believes that, any kind of understanding of social phenomena, must be given through an interpretation, carried out by using cognitive processes.

\section{Conclusions}

It was found that the digital inclusion is a complex phenomenon, that is composed by heterogeneous and inter-definable elements, where the adoption and appropriation of ICT are basic, to accomplish the goal of minimizing the digital gap. Therefore, taking this phenomenon as a complex system is a priority, and a necessity, in the theoretical and practical fields.

It was identified in the models that were revised, that the authors choose the variables for adoption and appropriation of ICT, which are the basis of their researches, without a proper justification of their use. Most of the models are focused on using a group of variables (individual or group), but in very few cases, both categories are simultaneously used.

It is considered that, an approach from sociocybernetics, allows the people who are interested in the phenomena of digital gap and digital inclusion, to understand better, the relations among heterogeneous and inter-definable elements that comprise it. Likewise, this approach provides elements, that allow configuring and tackling this phenomenon as a complex system, being a piece of a reality.

\section{References}

Almuwil, A., Weerakkody, V., \& El-Haddadeh, R. (2011). A conceptaul study of the factors influencing e-inclusion. In Proceedings of the European, Mediterranean and Middle Eastern Conference on Information Systems - Informing Responsible Management: Sustainability in Emerging Economies, EMCIS 2011 (pp. 198-209). conference, Athens.

Attri, R., Dev, N., \& Sharma, V. (2013). Interpretive Structural Modelling (ISM) approach: An Overview. Research Journal of Management Sciences, 2, 3-8.

Becerra, G. (2016). Sociocybernetics: Tensions between complex systems, social systems and complexity sciences. Athenea Digital, 16(3), 81-104. doi: http://doi.org/10.5565/rev/athenea.1636.

Billon, M., Marco, R., \& Lera-Lopez, F. (2009). Disparities in $\{\mathrm{ICT}\}$ adoption: A multidimensional approach to study the cross-country digital divide. Telecommunications Policy, 33(10-11), 596610. article. doi: http://dx.doi.org/10.1016/j.telpol.2009.08.oo6.

Dang, Y. M., Zhang, Y. G., Morgan, J. N., Cerdá Suárez, L. M., Distel, B., Ogonek, N., ... Alfarraj, O. (2011). Exploratory study on users' behavior: Smartphone usage. 16th Americas Conference on Information Systems 2010, AMCIS 2010, 23(3), 3356-3362. http://doi.org/10.1007/s12208-0150147-2

DeHann, J. (2004). A Multifaceted Dynamic Model of The Digital Divide. IT \& Society, 66-88.

Eagleman, A. N. (2013). Acceptance, motivations, and usage of social media as a marketing communications tool amongst employees of sport national governing bodies. Sport Management Review, 16(4), 488-497. doi: http://dx.doi.org/10.1016/j.smr.2013.03.004. 
Hinostroza, J., Matamala, C., Labbe, C., Claro, M., \& Cabello, T. (2015). Factors (not) affecting what students do with computers and internet at home. LEARNING MEDIA AND TECHNOLOGY, 40(1), 43-63. article. http://doi.org/10.1080/17439884.2014.883407.

Entezari, Y. (2015). Building Knowledge- Based Entrepreneurship Ecosystems: Case of Iran. Procedia Social and Behavioral Sciences, 195, 1206-1215. article. http://doi.org/http://dx.doi.org/10.1016/j.sbspro.2015.06.242.

Garcia, R. (2006). Sistemas complejos. conceptos, método y fundamentación epistemológica de la investigación interdisciplinaria. Barcelona: Gedisa.

Patricia Gonzalez-Zabala, M., Sanchez Torres, J. M., \& Galvis Lista, E. A. (2015). Identifying Factors that Affect the Development of Digital Inclusion. REVISTA VIRTUAL UNIVERSIDAD CATOLICA DEL NORTE, 44, 175-191. article.

Gupta, B., Dasgupta, S., \& Gupta, A. (2008). Adoption of $\{$ ICT $\}$ in a government organization in a developing country: An empirical study. The Journal of Strategic Information Systems, 17(2), 140-154. doi: http://dx.doi.org/10.1016/j.jsis.2007.12.004.

Koç, T., Turan, A. H., \& Okursoy, A. (2016). Acceptance and usage of a mobile information system in higher education: An empirical study with structural equation modeling. The International Journal of Management Education, 14(3), 286-300. http://doi.org/http://dx.doi.org/10.1016/j.ijme.2016.o6.oo1.

Kubiatko, M. (2013). The Comparison of Different Age Groups on the Attitudes toward and the Use of ICT. KURAM VE UYGULAMADA EGITIM BILIMLERI, 13(2), 1263-1272. article.

Maldifassi, J. O., \&Canessa, E. C. (2009). Information technology in Chile: How perceptions and use are related to age, gender, and social class. Technology in Society, 31(3), 273-286. doi: http://dx.doi.org/10.1016/j.techsoc.2009.03.006.

Michailidis, A., Partalidou, M., Nastis, S. A., Papadaki-Klavdianou, A., \& Charatsari, C. (2011). Who goes online? Evidence of internet use patterns from rural Greece. Telecommunications Policy, 35(4), 333-343. article. http://doi.org/http://dx.doi.org/10.1016/j.telpol.2011.02.006.

Nilashi, M., Ahmadi, H., Ahani, A., Ravangard, R., \& bin Ibrahim, O. (2016). Determining the importance of Hospital Information System adoption factors using Fuzzy Analytic Network Process (ANP). Technological Forecasting and Social Change, 111, 244-264. http://doi.org/http://dx.doi.org/10.1016/j.techfore.2016.07.008

Noce, A. A., \& McKeown, L. (2008). A new benchmark for Internet use: A logistic modeling of factors influencing Internet use in Canada, 2005. Government Information Quarterly, 25(3), 462-476. article. http://doi.org/http://dx.doi.org/10.1016/j.giq.2007.04.006.

Papaioannou, P., \&Charalambous, K. (2011). Principals' attitudes towards ICT and their perceptions about the factors that facilitate or inhibit ICT integration in primary schools of Cyprus. Journal of Information Technology Education:Research, 10(1), 349-369.

Pérez Serrano, G., \& Sarrate Capdevila, L. (2011). Las TIC promotoras de inclusión social. Revista Española de Pedagogía, 237-254.

Pick, J. B., Sarkar, A., \& Johnson, J. (2015). United States digital divide: State level analysis of spatial clustering and multivariate determinants of $\{\mathrm{ICT}\}$ utilization. Socio-Economic Planning Sciences, 49, 16-32. doi: http://dx.doi.org/10.1016/j.seps.2014.09.001.

Schleife, K. (2010). What really matters: Regional versus individual determinants of the digital divide in Germany. Research Policy, 39(1), 173-185. article. http://doi.org/http://dx.doi.org/10.1016/j.respol.2009.11.003. 
Sepúlveda López, J. J., \& Ramírez Castañeda, L. A. (2015). The complexity of digital inclusion Relevance of the social perspective. In R. L. Isaias P. (Ed.), Proceedings of the 14th International Conference WWW/Internet 2015 (pp. 223-226). IADIS. Retrieved from https://www.scopus.com/inward/record.uri?eid=2-s2.0-

84958543039\&partnerID=40\&md5=cocf43654c79fiocf52991e2bib597bb.

Sun, H., \& Zhang, P. (2006). The role of moderating factors in user technology acceptance. International Journal of Human-Computer Studies, 64(2), 53-78. article. doi: http://dx.doi.org/10.1016/j.ijhcs.2005.04.013.

Taipale, S. (2013). The use of e-government services and the Internet: The role of socio-demographic, economic and geographical predictors. Telecommunications Policy, 37(4-5), 413-422. http://doi.org/http://dx.doi.org/10.1016/j.telpol.2012.05.005

Teles, A., \&Joia, L. A. (2010). Assessment of digital inclusion via the actor-network theory: The case of the Brazilian municipality of Piraí. Telematics and Informatics, 1-13.

Thill, M. C., Rosenzweig, J. W., \& Wallis, L. C. (2016). The Relationship Between Student Demographics and Student Engagement with Online Library Instruction Modules. EVIDENCE BASED LIBRARY AND INFORMATION PRACTICE, $11(3), \quad 4^{-15}$. http://doi.org/http://dx.doi.org/10.18438/B8992D.

Thompson, K. M., Jaeger, P. T., Greene Taylor, N., Subramaniam, M., \&Bertot, J. C. (2014). Digital Literacy and Digital Inclusion - Information Policy and the Public Library. Rowman \&Littkefield.

Dubey, R. ., \& Singh, T. . (2015). Understanding complex relationship among JIT, lean behaviour, TQM and their antecedents using interpretive structural modelling and fuzzy MICMAC analysis. TQM Journal, 27(1), 42-62. http://doi.org/10.1108/TQM-09-2013-0108.

Trivedi, P., \& Dubey, A. (2012). Implementation of KM in Indian SMEs: Modeling the variables. In 2012 1st International Conference on Recent Advances in Information Technology, RAIT-2012 (pp. 493-498). Dhanbad. http://doi.org/10.1109/RAIT.2012.6194628.

Tuan, N.-T. (2017). Interpretive Structural Modelling in Action - A Preliminary Exploration of \{AIDS\} Pandemic in South Africa. Procedia Engineering, 182, 717-724. http://doi.org/https://doi.org/10.1016/j.proeng.2017.03.186.

Watson, R. H. (1978). Interpretive structural modeling-A useful tool for technology assessment? Technological Forecasting and Social Change, 11(2), 165-185. http://doi.org/http://dx.doi.org/10.1016/o040-1625(78)90028-8

Weber, D. M., \& Kauffman, R. J. (2011). What drives global $\{$ ICT $\}$ adoption? Analysis and research directions. Electronic Commerce Research and Applications, 10(6), 683-701. http://doi.org/http://dx.doi.org/10.1016/j.elerap.2011.01.0o1 